\title{
Family Communication Pattern to the Development of Children's Emotional Intelligence (EQ) Related to the Low Socioeconomic Background at TK Amaliah Al- Ilmi Bekasi, Indonesia
}

\author{
S Mansur ${ }^{1}$, A S Ramadhani ${ }^{2}$ \\ 1,2 Universitas Mercu Buana, Jakarta \\ 1uraya.suraya@mercubuana.ac.id, ${ }^{2}$ nisasekar14@gmail.com
}

\begin{abstract}
Amaliah Al-Ilmi Bekasi Kindergarten for children from families with low socioeconomic status in Pekayon, South Bekasi. Measurement of the socioeconomic status of a family can be viewed from factors of the environment of residence, parental education level, type of work, income and expenses of a family. The aims of this study: (1) Parent and child communication patterns in school at Amaliah Al-Ilmi Kindergarten Bekasi, (2) The extent of understanding and family awareness of the importance of family communication patterns on the development of children's emotional intelligence. The type of research that researchers use is descriptive qualitative, through the case study method. Data collection techniques are interviews and observation of four research subjects. The results showed that the dominant communication patterns applied by the four research subjects were pluralistic and protective families. Parental understanding and awareness of the importance of family communication on children's emotional development are quite low. Communication patterns that give children the freedom to express and discuss anything have better emotional intelligence development compared to families who apply family communication patterns with less communication intensity and closed conversations. Contribution: Parents need to understand that emotional intelligence is as important as cognitive intelligence.
\end{abstract}

Keywords: Children, Emotional Quotient, Family Communication Pattern, Low Socioeconomic Families

\section{INTRODUCTION}

Amaliah Al-Ilmi is a kindergarten established by a Bekasi resident, Rita Thaher, since 2008. Embarking from her garage as a teaching activity for children who come from an underprivileged background. In 2017, an estimated 58 children and with an addition of 40 students in 2018. Since the first establishment, Amaliah Al-Ilmi Kindergarten merely accepting students coming from underprivileged families.

During the teaching process, there are unnoticed things by the founder, is that the students there, could not solely depend on teacher role which only has two hours in contrast to their own parents who have all the time, in their home. Other than limited educational opportunity, the time that the parents possess to be at home is also limited as they unavoidably have to make a living. The majority of the parents are working as a household 
assistant, selling things, or working on construction sites. This is another challenge for the kindergarten to educate parents on how to interact with children, how to build children's character, as well as how to educate children under such circumstances.

Parents tend to focus on children cognitive intelligence which is often called Intelligence Quotient (IQ.) Through formal and informal education, parents educate children on schools and send them to specialized courses and other efforts to increase their children's IQ. Despite the fact that Emotional Quotient (EQ) is as important as IQ because it is strongly correlated with other quotients, such as social, moral, interpersonal, and spiritual quotients.

Based on online news media okezone.com in March 2018, a violent act that included children in Bekasi has been gradually increasing. KPAID justifies that there are 198 children abused along 2017. This number has been increasing compared to cases in 2016 which have 127 cases.

Mrs. Mimin one of the teachers in Amaliah Al-Ilmi Kindergarten, 13 students showed difficulties in socializing and lack of confidence. 7 students tend to weep, lack motivation and not persistent in doing something. There are 5 students who tend to be egoistic, playful, filled with rage and will be ended up fighting with others. On the other hand, there are 15 students who are rather active, confident, easy to be approached, and have a lot of sympathies. The information given by the teachers showed that there is social quotient diversity which can be seen in their behavior. This might be caused by different communication patterns in each family despite they come from lower-class families.

Research on communications[1] and family communications had been done by Fitzpatrick[2]; about family communications in creating identity[3]; Family Communications Patterns and Functions[4] [5]; Family Functions[6][7] [8]; relationship between Family Communication and an individual emotional intelligence[9][10][11]; Character building[12][13]; Constructing Akhlakul karimah[14][15]; Children's Intimacy Level[16][17]. While research on child intelligence development was done by Andriani[18] about increasing student achievement; Quality of Life in High school Student[19][20]; Communication Pattern with Emotional Quotient[10].

This research focused on "Communication Patterns of Low Socio-Economic Households in Building Children Emotional Intelligence Development" by a case study in Amaliah Al-Ilmi Kindergarten as a medium to see the application of family communication patterns to children emotional quotient. How are family understanding and awareness of the importance of family communication patterns on the development of children's emotional intelligence?

Family communication is an interchanging message on a group that holds ties and related by blood or because of marriage. According to Rae Sedwig (1985) in research[3], family communications is an organization that uses words, gestures, the intonation of sounds, actions to create hope/images, expressions of feelings and mutual understanding[10][9][21]. There are several forms of communication used in families according to Subramanian[22] namely: (1) Verbal Communication (2) Non-Verbal Communication (3) Group Communication (4) Interpersonal Communication

According Fitzpatrick[2], family communication patterns can be measured or determined based on two dimensions, namely conversation orientation and conformity orientation. Conversation orientation is the extent to which the family creates an atmosphere where every family members are free to participate and interact with each other on a variety of topics. Each family member spends a lot of time sharing stories of personal activities, thoughts, feelings, mutual respect for the exchange of ideas or opinions, decisions made in the family are made after being discussed together[4] 
The dimension of conformity orientation is the extent to which the family creates an atmosphere that emphasizes the homogeneity of attitudes, values, and beliefs. Families with high dimensions of conformity have interactions that emphasize uniformity of beliefs, attitudes, and interactions that focus on harmony, obedience to parents or other adults, and interdependency to family members. Families with low conformity are characterized by heterogeneous attitudes and beliefs, individualist family members, and interactions that focus on the uniqueness of each family member.[4]

Family communication patterns according to Koerner and Mary Ann Fitzpatrick[4]LittleJohn [23], there are four patterns of family communication, which are: (1) Consensual Families. Families that have a high orientation to conversation and conformity. (2) Pluralistic Families. Families who have a high orientation to the conversation and low conformity. (3) Protective Families. This family has a low conversation orientation but high conformity orientation. (4) Laissez-faire Families. This family has a low orientation both in conversation and in conformity.

Intelligent Quotient is one's general ability to take actions that posses goals in certain situations. Intelligence is something that can be fostered and studied. According to Andriani[18], intelligence is an ability to learn, the overall knowledge obtained, and the ability to adapt to new situations or the environment in general. Whereas intelligence according to Amini et All [10] is the ability or skill to solve problems or create valuable products in one or more specific cultures. Another opinion expressed by C. P. Chaplin who said intelligence is the ability to deal with and adapt to new situations precisely and effectively. According to Daniel Goleman[24], emotions refer to a specific feeling and thought, a biological and psychological state and a series of tendencies to act.

Goleman[10][24] identifies emotions as follows: Anger (hatred, offense, hostility, and acts of violence). Sadness (loneliness, depression, self-pity, despair, and melancholy). Fear (anxiety, worry, phobia, panic, and nervousness). A sense of pleasure (pleasure, satisfaction, and happy feelings). Love (kindness, closeness, affection, trust, and love). Shock (wonder and awe). Annoyed (sense of humiliation, disgust, and dislike). Shame (feelings of guilt, regret, and resentment).

Justified by Mayer and Salovey[18] emotional quotient is a subset of social intelligence that involves the ability to monitor feelings and emotions both in oneself and in others, sorting out, and use this information to lead their thoughts and actions. Someone's character, behavior, actions, and interactions depend on his emotional intelligence. There are 5 basic skills or aspects of emotional intelligence, expressly: (1) Self-Awareness. (2) SelfRegulation (3) Motivation (4) Empathy (5) Social Skills [23].

Development of Emotional Intelligence in Children According to Cherniss [25][26] the ability of children to react emotionally already exists since the child is a fetus. Children possess talents inherited from their parents. The first symptom of emotional behavior is general stimulation. As a child grows older, a child's emotional intelligence is influenced by his or her environment starting from the smallest environment, which is the family and later to the community. At this stage, children begin to differentiate and learn from other people's reactions

\section{RESEARCH METHOD}

This study deployed a constructivist paradigm with the Case Study research method[27] qualitative descriptive. The method to collect the data is in-depth interviews and observations. The informants of this study were determined by purposive sampling. The key 
informant was Ms. Rita Thaher, founder of the Amaliah Al-Ilmi Kindergarten, which was devoted to underprivileged families. Secondly, Mrs. Mimin should be the principal who regulates and controls all activities in the school.

The informants of this study were the families whose children are students in Amaliah Al-Ilmi Kindergarten, namely: (1) Moh Ilham Maulana Darmawan's family. (2) The Fanello Rizky Hasan family. (3) Nessya Robbani's family. (4) Kintan Magfirani's family.

Data analysis techniques using interactive models[27] consist of Data Reduction, Data Display, Conclusion Drawing /Verification. Testing the validity of research using source triangulation techniques.

\section{RESULTS AND DISCUSSION}

Fanello's and Kintan family dominantly applying a pluralistic communication pattern. Both Fanello and Kintan's family give freedom to their family members to communicate and discuss. Everyone is free and open to opinion. This makes Fanello and Kintan have the ability to interact and communicate well. Both become more active individuals because they are accustomed to talking about all kinds of topics like daily activities, as well as something they want to know and about their own feelings. Not only active, but also both become more confident. Fanello and Kintan were encouraged by the communication patterns adopted by their families to express their opinions, ideas or thoughts. Each family believes that with freedom and openness of communication, children are getting used to be able to reason properly. When viewed from the intensity of communication within Fanello family and Kintan family, both have a fairly frequent communication intensity.

The intensity of communication that occurs in a family plays an important role in conveying a message or information. Especially if parents want to shape and build the children's abilities and character, communication intensity is needed, as applied by Fanello and Kintan families. Kintan said: "Yes, I am trying not to latch her with prohibitions, I would let her do what she wants especially if she got anything that makes her curious, but she does not really ask that much. So, I let her explore her curiosity as long as it is good for her. If it is not, I would explain more and show attention to her".

Kintan's mother makes communication as a tool to equalize meanings. Communication is used as a means of educating children and socializing to children which they think is good and why it is good. Her mother tried to shape her character through communication. She explained: "She is a brave girl. So, what I want to develop on her is that Kintan has to be independent and disciplined. Everything needs to be done independently, I do not even pick her up when the school is over. " She added, "To me, the most important things to look out are these two things, independent and discipline. The other things are acceptable, even for her Father. In my opinion, those two aspects are the most important."

The same goes for Fanello family. His mother emphasized values to Fanello through communication. His mother attempt to shape the character of the child. She said: "As long as he knows how to manage his time. Other than that, I would still try to listen to what he wants". Both families give their children freedom, not too strict nor rigid about the rules. For their families, all decisions can be discussed together with opinions from other family members. Thus, the dimension of conformity orientation in these two families has a low level of homogeneity in attitudes, values, and beliefs.

Nessya and Ilham's families tend to adopt protective communication patterns. In families with protective communication patterns have a low conversation orientation but high conformity orientation. Conversations between family members are rarely done. 
Families rarely interact with each other because in families which apply this communication pattern not all topics can be discussed together.

Conversations that occur are only limited to routine, instead, they do not try to make communication as the main means to educate and shape the character of children. Children in these types of families with this communication pattern are not accustomed to expressing their feelings or opinions. Communication limitations made Nessya reserved. It is not easy for her to get along especially in a new environment. Nessya finds it difficult to socialize, to friends on her age as well as with her teacher. She will speak only if she is asked to. But because his mother makes a living by herself, her mother did not have enough time to communicate deeply to Nessya.

Nessya's family has a traditional family structure. Likewise with Ilham's family. In Ilham's family, all family decisions are decided by his father. His mother said his father was quite strict in educating Ilham. Ilham has to obey all the decisions and regulations made by his father. The same goes for his mother who followed the decision set by his father. Strict parenting makes Ilham rather strict. He sometimes asked why he had to carry out orders or obey the rules created by his father. His mother sometimes explained it to Ilham. She said: "Usually I or his father would explain that he just has to obey his parents, don't fight back, don't be stubborn."

The application of the dominant pluralistic communication pattern in Fanello's family. Fanello's emotional intelligence is considered good. Fanello became an active child by communicating and asking questions. This is because Fanello is accustomed to being open and free to communicate with his parents. His self-confidence makes him easy to get along and has many friends. He also became a child who was quite tactful and sensitive because his family was accustomed to being open to each other's emotions and feelings. So that makes him have a sense of empathy in his surroundings.

Fanello's family is open to all the possibilities, opinions and questions from children. Children are free to express their opinions as long as they are good. If a child's opinion is not proper, Fanello's parents will explain the reasons why it is not good and vice versa. For Fanello's family, the most important thing is that Fanello is able to manage and appreciate the time. The decision remains with parents for children's opinions. Fanello family can be categorized as having a fairly low dimension of conformity orientation.

The dimension of conversation orientation in Nessya's family is relatively low. Nessya's family has a traditional family structure. This can be seen from all the decisions made by her parents, namely Nessya's Mother. Her mother hoped that Nessya could follow all of her decisions without questioning. Although sometimes Nessya cries if she disagrees with her mother, her mother often gives regulative messages so that Nessya obeys and has an equal belief and attitude. Interaction is carried out in order to strengthen the traditional family structure. Therefore, the conformity orientation dimension is quite high.

The dimension of the conformity orientation of Ilham's family tends to be high. His family considers that all decisions are in the hands of parents, especially the father in the family. Parents expect diverse beliefs and attitudes of children. Children are expected not to ask many questions about the decisions that have been set and carry out their duties as a child, which is to study. The application of the dominant communication pattern in Ilham's family makes Ilham passive, quiet at school, and sensitive person. This is because his father Ilham's communication with Ilham was rather strict. His father is quite harsh when it comes to regulations at home. The discussion applied is not in-depth but only to convey regulative messages to strengthen the position of parents. In Ilham's family, the decision is only made by his father. 
Family socioeconomic conditions affect the ability of parents and children to communicate, children to parents, parents to the environment, children to the environment. The socio-economic condition of the family influences how families interact with one another. The conditions start with parental education, social status, living environment, and daily activities. The socio-economic condition of the family influences how parents form communication patterns to children that affect children's emotional intelligence.

\section{CONCLUSIONS}

Parental understanding and awareness of the importance of family communication on children's emotional development are quite low. Although family considers communication important, on its application, communication is only considered to be limited to routine and is not something that has meaning for children's development. The family also does not have a deep understanding of emotional intelligence. Families pay more attention to children's cognitive abilities. Although the emotional ability of children is a basic thing from other quotients. Families who apply pluralistic communication patterns have a better understanding. Kintan's family emphasizes the independence and discipline of children. Whereas Fanello's family, the family emphasizes Fanello in order to appreciate the time. This is a small part of the application of communication for the development of children's emotional intelligence. The application of appropriate family communication patterns is positive for the development of children's emotional intelligence.

\section{REFERENCES}

[1] F. F. Basarah, "MEDIA SOSIAL SEBAGAI SARANA EKSISTENSI DIRI (Reception Analysis Mahasiswa Fakultas Ilmu Komunikasi Universitas Mercu Buana Angkatan 2016)," Communicology J. Ilmu Komun., 2018.

[2] M. A. Fitzpatrick, "Family Communication Patterns Theory: Observations on Its Development and Application," J. Fam. Commun., 2004.

[3] Beely Jovan Sumakul, "PERANAN KOMUNIKASI KELUARGA DALAM PEMBENTUKAN IDENTITAS REMAJA DI KELURAHAN MALALAYANG I KECAMATAN MALALAYANG KOTA MANADO,” e-journal “Acta Diurna,” 2016.

[4] A. F. Koerner and M. A. Fitzpatrick, "Chapter 2: Understanding Family Communication Patterns and Family Functioning: The Roles of Conversation Orientation and Conformity Orientation," Commun. Yearb., 2002.

[5] F. A. Koerner and F. Mary Anne, "Understanding Family Communication Patterns and Family Functioning: The Roles of Conversation Orientation and Conformity Orientation," Ann. Int. Commun. Assoc., 2002.

[6] "Pengaruh Pola Komunikasi Keluarga dalam Fungsi Sosialisasi Keluarga terhadap Perkembangan Anak," J. KMP (Jurnal Komun. Pembangunan), 2010.

[7] A. F. Koerner, "Family communication," in Interpersonal Communication, 2014.

[8] K. M. Smith, P. A. Freeman, and R. B. Zabriskie, "An examination of family communication within the core and balance model of family leisure functioning," Fam. Relat., 2009.

[9] J. Keaten and L. Kelly, "Emotional intelligence as a mediator of family communication patterns and reticence," Commun. Reports, 2008.

[10] M. Amini, M. Amini, P. Nabiee, and S. Delavari, "The relationship between emotional 
intelligence and communication skills in healthcare staff," Shiraz E Med. J., 2019.

[11] R. Abbasi-Asl, H. Naderi, and A. Akbari, "Mediating Role of Emotional Intelligence Between Family Communication Patterns and Achievement Motivation Among High School Students," Int. J. Sch. Heal., 2017.

[12] I. Rakhmawati, "Peran Keluarga dalam Pengasuhan Anak," Jurnalbimbingan Konseling Isla, 2015.

[13] D. Satya Yoga, N. W. Suarmini, and S. Prabowo, "Peran Keluarga Sangat Penting dalam Pendidikan Mental, Karakter Anak serta Budi Pekerti Anak,” J. Sos. Hum., 2015.

[14] H. Purnomo, "Peran Orang Tua dalam Optimalisasi Tumbuh Kembang Anak untuk Membangun Karakter Anak Usia Dini,” Pros. Semin. Nas. Parent., 2013.

[15] Y. T. Wijayanti, "Pola Komunikasi Keluarga dalam Membangun Akhlakul Karimah," CHANNEL J. Komun., 2015.

[16] C. A. Barbato, E. E. Graham, and E. M. Perse, "Communicating in the Family: An Examination of the Relationship of Family Communication Climate and Interpersonal Communication Motives," J. Fam. Commun., 2003.

[17] Y. Setyowati, "Pola Komunikasi Keluarga dan Perkembangan Emosi Anak (Studi Kasus Penerapan Pola Komunikasi Keluarga dan Pengaruhnya terhadap Perkembangan Emosi Anak pada Keluarga Jawa),” J. ILMU Komun., 2013.

[18] A. Andriani, "Kecerdasan Emosional (Emotional Quotient) dalam Peningkatan Prestasi Belajar," Edukasi, 2014.

[19] E. R. Wijhati and S. Suharni, "Pelatihan Pendidikan Seks Anak Usia Dini Pada Kader 'Aisyiyah Ranting Pandeyan Kecamatan Umbulharjo Kota Yogyakarta," AKSIOLOGIYA J. Pengabdi. Kpd. Masy., 2018.

[20] A. Bandura, G. V. Caprara, C. Barbaranelli, C. Regalia, and E. Scabini, "Impact of family efficacy beliefs on quality of family functioning and satisfaction with family life," Appl. Psychol., 2011.

[21] F. Tajalli and M. Latifian, "The effect of family communication patterns on mental health with mediation of emotional intelligence," J. Fam. Res., 2008.

[22] K. . R. Subramanian, "Influence of Social Media in Interpersonal Communication," Int. J. Sci. Prog. Res., 2017.

[23] Stephen W. Littlejohn, THEORIES OF HUMAN COMMUNICATION Eleventh Edition. 2012.

[24] Goleman, "PENTINGNYA KECERDASAN EMOSIONAL SAAT BELAJAR," Ilm. Inov., 2014.

[25] C. Cherniss, C. Roche, and B. Barbarasch, "Emotional Intelligence," in Encyclopedia of Mental Health: Second Edition, 2016.

[26] V. L. Schwean, D. Saklofske, L. Widdifield-Konkin, J. D. A. Parker, and P. Kloosterman, "Emotional Intelligence and Gifted Children," E-Journal Appl. Psychol., 2006.

[27] R. K. Yin, Case study research: Design and methods (5th ed.). 2014. 